\title{
Extra-insular beta cells associated with ductules are frequent in adult human pancreas
}

\author{
L. Bouwens, D. G. Pipeleers \\ Diabetes Research Center, Free University of Brussels, Belgium
}

\begin{abstract}
Summary Routine immunohistochemical analysis of human donor pancreata indicated the frequent occurrence of single insulin-immunoreactive cells. In a quantitative analysis of nine organs consecutively recruited from adult donors, 15 percent of all beta cells were found in units with a diameter less than $<20 \mu \mathrm{m}$ and without associated glucagon-, somatostatin-, or pancreatic polypeptide cells. These single beta-cell units are located in or along ductules, from which they appear to bud as previously noticed in fetal and neonatal organs. They contain significantly smaller beta cells than endocrine aggregates with a larger diameter. The use of ductal cell markers such as cytokeratin 19, carbonic anhydrase-II and carbohydrate antigen 19.9 identified a close topographical associa-
\end{abstract}

tion between ductal cells and budding beta cells; it also indicated that pancreatic lobules are composed of nearly one third ductal cells. The presence of Ki67 proliferation marker-immunoreactive ductal cells $(0.05 \%)$ and absence of Ki67-immunoreactive budding beta cells is compatible with the view that betacell neogenesis depends on ductal cell proliferation and differentiation. The high proportion of budding beta cells in the adult human pancreas suggests the presence of numerous loci with a potential for betacell neogenesis. [Diabetologia (1998) 41: 629-633]

Keywords Beta cell, duct, islet, proliferation, differentiation, neogenesis.
The light-microscopic structure of the mammalian pancreas is characterized by a lobular arrangement of exocrine acini which are interconnected by ducts. Intercalated ducts are the smallest branches of the intralobular ducts and penetrate the acinus to terminate in centroacinar cells. It is generally assumed that pancreatic lobules are mainly composed of acinar cells with only a small proportion of ductal cells [1]. It is not known whether the postnatal ductal system is a source for new islet cells as it is in the prenatal stage $[2,3]$. The present study investigates whether ductal cells in the adult human pancreas are also associated with pancreatic endocrine cells as has

Received: 6 November 1997 and in final revised form 9 February 1998

Corresponding author: Dr. L. Bouwens, Department of Experimental Pathology, Vrije Universiteit Brussel, Laarbeeklaan 103, B-1090 Brussels, Belgium been observed in fetal pancreata [3]. This work takes advantage of the ability to recognize ductal cells through immunocytochemical markers. Cell proliferation was also assessed immunocytochemically.

\section{Materials and methods}

Collection and preparation of tissue. Human pancreasta from heart-beating cadaveric non-diabetic donors were procured under the auspices of a European multicentre programme on islet cell transplantation. Upon arrival at the control unit in Brussels, fragments were taken from the pancreatic body and the remaining tissue was then digested for islet isolation. Fragment sections were examined microscopically after fixation in $4 \%$ formaldehyde and embedding in paraffin [4]. The quantitative data reported in this study were collected in tissue samples from 9 consecutive donor organs. Donors (5 men, 4 women) were between 17 and 49 years of age. Tissue was also obtained during autopsy, within $6 \mathrm{~h}$ after death, from three patients who died from either cardiogenic shock, bronchopneu- 
Table 1. Antibodies used in this study

\begin{tabular}{llllll}
\hline Antigen & & & \multicolumn{2}{l}{ Antibody } & \multirow{2}{*}{$\begin{array}{l}\text { Working } \\
\text { dilution }\end{array}$} \\
\cline { 1 - 2 } Name & Species & & Type & Species & \\
\hline Insulin & Pig & & $\mathrm{P}$ & guinea-pig & $1: 5000$ \\
Glucagon & Pig & $\mathrm{P}$ & rabbit & $1: 5000$ \\
Somatostatin & Human & $\mathrm{M}$ & mouse & $1: 5000$ \\
PP & Human & $\mathrm{P}$ & rabbit & $1: 2000$ \\
Carbonic anhydrase-II & Human & $\mathrm{P}$ & rabbit & $1: 100$ \\
Cytokeratin 19 & Human & $\mathrm{M}$ & mouse & $1: 100$ \\
CA19.9 & Human & $\mathrm{M}$ & mouse & $1: 200$ \\
Ki-67 & Human & $\mathrm{M}$ & mouse & $1: 100$ \\
\hline
\end{tabular}

$\mathrm{P}=$ polyclonal, $\mathrm{M}=$ monoclonal

monia, or oesophagal carcinoma (one man, 51 and two women, 74 and 75 years of age). Tissue samples were taken from the anterior lobe ("head"), the middle ("body") and the tail part ("tail") of the gland in the autopsy cases. This study was approved by the university's ethical committee.

Immunohistochemistry. Immunohistochemical investigation was performed on paraffin sections ( $4 \mu \mathrm{m}$ thick) using the streptavidin-biotin-peroxidase or alkaline phosphatase method [3-5], with anti-insulin and anti-glucagon (obtained from C. Van Schravendijk, Vrije Universiteit Brussel, Brussels), anticarbonic anhydrase-II (from A-K Parkkila, University of Oulu, Oulu, Finland), anti-pancreatic polypeptide (PP; from R.E. Chance, Lilly Research, Indianapolis, USA), anti-cytokeratin 19 (clone RCK108, purchased from Dako, Glostrup, Denmark), anti-carbohydrate antigen 19.9 (CA19.9/syalyl-Lewis ${ }^{\text {a }}$ from CIS, St-Quentin-Yvelines, France), anti-Ki-67 (clone MIB-1; from Immunotech, Marseille, France), and anti-somatostatin (clone SOM-08, Novo-Nordisk, Bagsvaerd, Denmark). Table 1 gives more details on these antibodies. Negative controls procured by ommitting the primary antibody resulted in the absence of immunoreactive staining. For morphometry, insulin-immunoreactive cell areas were manually traced using a colour video camera connecting the microscope and a computer with NIH Image 1.41 software (public domain, USA) [4, 5].

Statistical analysis. Statistical significance was assessed by Student's $t$-test.

\section{Results}

Frequency of single beta cells. During routine analysis of the numerous tissue samples that were examined as part of the islet transplantation programme, we noticed a high frequency of small insulin-immunoreactive cell clusters which we defined as units comprising 3 cells at a maximum(Fig. 1 a). Serial sectioning confirmed that these small beta-cell units did not form part of larger islet structures and were not associated with other endocrine islet cells as identified by immunoreactivity for glucagon, somatostatin or PP. A quantitative morphometric analysis was undertaken on tissue from 9 organs which were collected consecutively at the central unit. We determined the mean surface area of single insulin-immunoreactive cells $\left(87.6 \pm 4.4 \mu \mathrm{m}^{2}\right)$ and then measured the contribution
Table 2. Quantification of single beta-cell units (area and relative cell number) and total beta-cell area in human pancreas sections

\begin{tabular}{|c|c|c|c|c|}
\hline \multicolumn{2}{|l|}{ Donor } & \multicolumn{2}{|c|}{$\begin{array}{l}\text { Single beta cells/ } \\
\text { total beta cells: }\end{array}$} & \multirow{2}{*}{$\begin{array}{l}\text { Total beta- } \\
\text { cell area/sec- } \\
\text { tion area }(\%)\end{array}$} \\
\hline Age (years) & Sex & $\%$ of area $^{\mathrm{a}}$ & $\%$ of cells & \\
\hline 17 & $\mathrm{~F}$ & 15.5 & 21.9 & 0.35 \\
\hline 17 & M & 8.9 & 16.3 & 0.49 \\
\hline 19 & M & 9.7 & 17.0 & 0.55 \\
\hline 26 & $\mathrm{~F}$ & 7.8 & 11.0 & 0.39 \\
\hline 28 & M & 9.0 & 14.4 & 0.59 \\
\hline 39 & M & 6.9 & 17.3 & 0.52 \\
\hline 45 & $\mathrm{~F}$ & 18.8 & 13.2 & 0.19 \\
\hline 48 & $\mathrm{~F}$ & 4.3 & 16.4 & 0.34 \\
\hline 49 & M & 2.3 & 9.2 & 0.49 \\
\hline Means $( \pm \mathrm{SE})$ & $32.0 \pm 4.5$ & $9.2 \pm 1.7$ & $15.2 \pm 1.3$ & $0.43 \pm 0.04$ \\
\hline
\end{tabular}

${ }^{a}$ sum of insulin-immunoreactive areas $<300 \mu \mathrm{m}^{2} \times 100$ (divided by) total insulin-immunoreactive area in the section

of units, comprising at maximum three insulin-immunoreactive cells (i.e. individual area less than $300 \mu \mathrm{m}^{2}$, or diameter $<20 \mu \mathrm{m}$ ), to the total surface area occupied by the insulin-immunoreactive cells in the pancreatic sections. First, it was noticed that the individual beta-cell area within these units was smaller than within the islets with a larger diameter, i.e. $87.6 \pm 4.4 \mu \mathrm{m}^{2}$ compared with $138.6 \pm 6.3 \mu \mathrm{m}^{2}$ $(p<0.002)$. Second, the area of small beta-cell units, hereinafter referred to as single beta-cells, was found to represent $9.3 \%$ of the total beta cell area. In relative cell number, the single beta cells represented $15 \%$ of all beta cells that were identified as nucleated insulin-immunoreactive cells in the sections. The total insulin-immunoreactive area in these sections contributed to $0.43 \%$ of the total section area (Table 2).

A similar quantification was conducted on pancreatic tissue collected from autopsy cases, in order to exclude possible regional differences in the gland. Our donor-data were obtained in tissue samples taken from the body of the gland. The single beta-cell areas in the autopsy pieces taken from the head represented $9.2 \%$, and that from the body and tail $10.5 \%$, and $8.7 \%$ of the total insulin-immunoreactive area. These percentages neither differed from each other nor from those measured in the samples from organ donors $(p>0.05)$. There was also no difference in the total insulin-immunoreactive area (data not shown). These data indicate that single beta cells are equally distributed throughout the whole gland.

Frequency of ductal cells. Immunohistochemical investigation of the ductal cell markers cytokeratin-19, carbonic anhydrase-II, and carbohydrate antigen19.9 (syalyl-Lewis-a) showed a high density of immunoreactive cells in the exocrine lobules (Fig. 1b-d). Cytokeratin-19 and carbohydrate antigen-19.9 yielded the best immunoreactivity, namely a distinct delineation and intense staining of the ductal cells. Most 


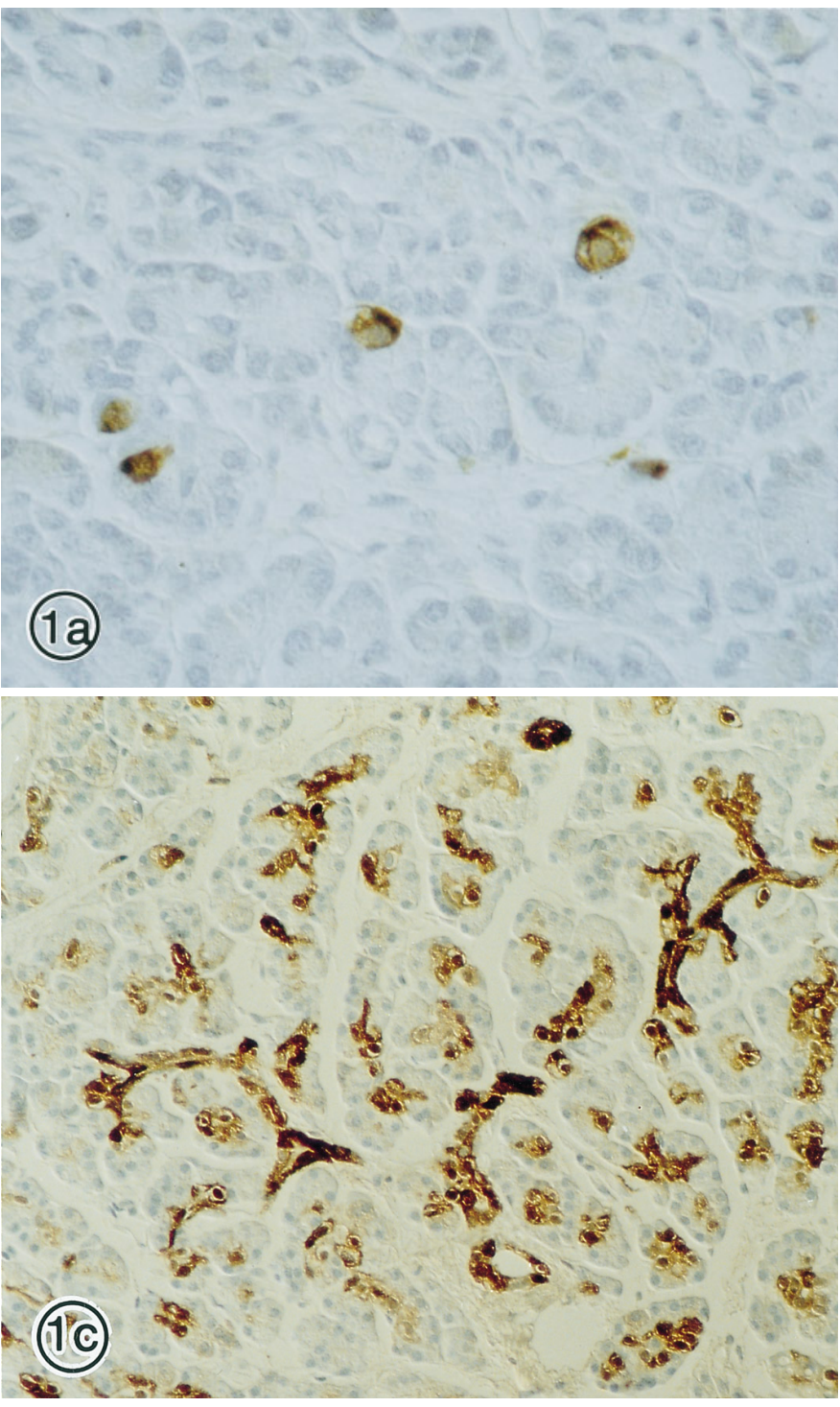

Fig. 1a-d. Immunohistochemical localization (brown colour) in human pancreas of: insulin (a), cytokeratin 19 (b), carbonic anhydrase-II (c), and carbohydrate antigen 19.9 (d). Note the single beta cells scattered in the exocrine parenchyma (a), and the numerous intercalated ductules and centroacinar cells (b-d). A large islet (asterisk) is seen in (d). Magnification: $\times 400$ (a) and $\times 100(\mathbf{b}-\mathbf{d})$

immunoreactive cells occurred in intercalated ductules or as centroacinar cells; a minority was present in the larger intralobular ducts. These markers were also strongly expressed in interlobular ducts but were absent in acinar cells which we recognized by their larger size, shape, and zymogen granules. Within the pancreatic lobuli, $33 \pm 2 \%$ (range: 26-36), $27 \pm 2 \%$ (range: $22-33$ ) and $32 \pm 1 \%$ (range: $27-35$ ) of the cells were immunoreactive for, respectively, cytokeratin-19, carbonic anhydrase-II, and carbohydrate antigen-19.9. Thus, nearly one third of the parenchyma in pancreatic lobules consists of ductal
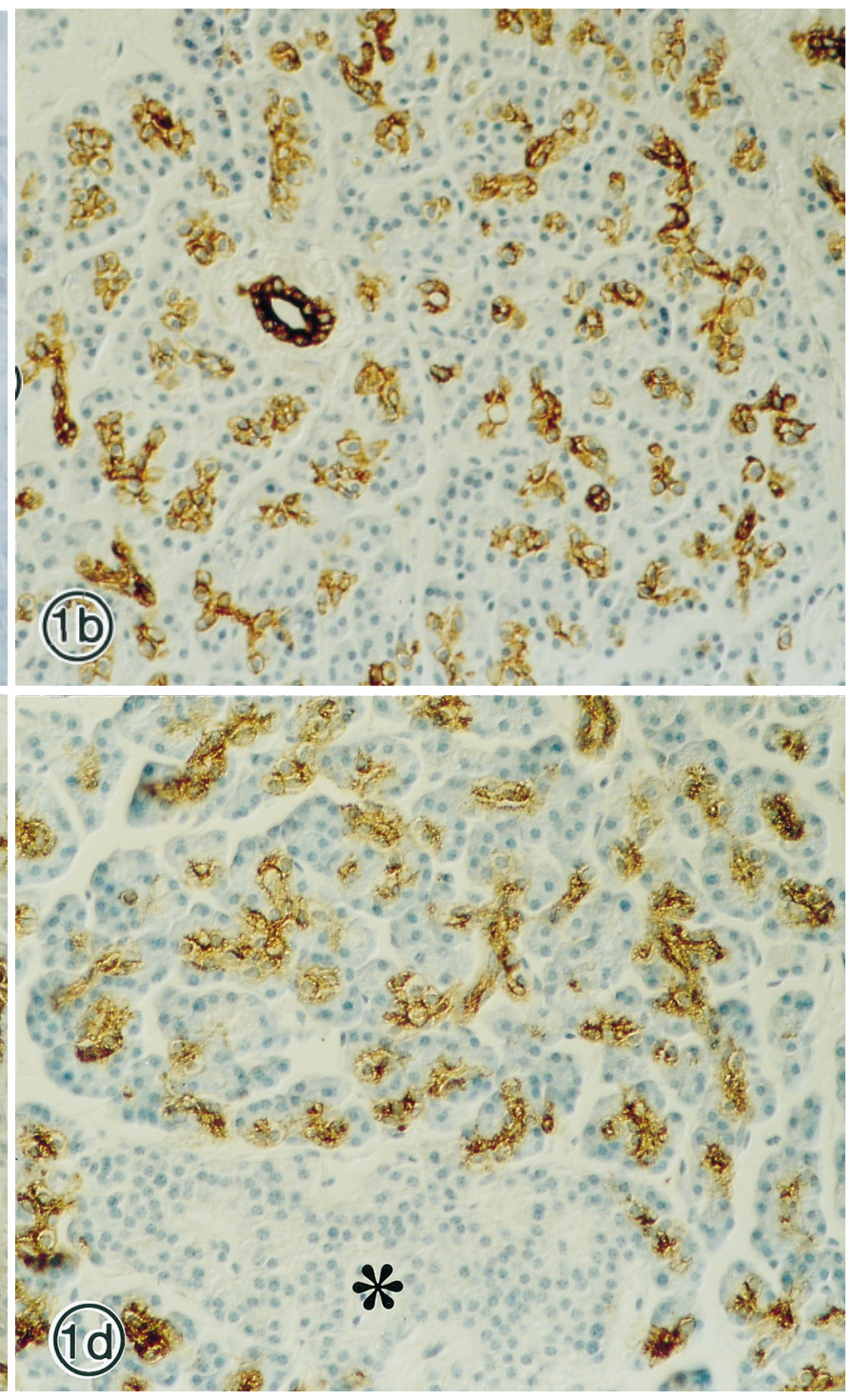

cells. A similar density of ductal cells was observed in the head, body and tail of the gland (data not shown).

Topographic relation between beta cells and ductal cells. Double immunohistochemical localization of ductal markers (keratin-19 or carbonic anhydrase) and insulin indicates that single beta cells frequently occur in direct contact with ductular cells located in intercalated ductules or acinar centres (Fig. 2a,c,d). Larger aggregates of beta cells tended to be associated with larger ducts (Fig. 2b). These structural contacts are suggestive of a continuity between ductal and endocrine epithelia. Cell doublets ("daughter cells") could be discerned, i. e. two adjacent cells one of which is immunoreactive for a ductal marker and the other for insulin (Fig. 2c). Insulin/cytokeratin-19 or insulin/carbonic anhydrase double immunoreactive cells were only rarely seen and exhibited a polarity with insulin located at one pole and cytokeratin-19 or carbonic anhydrase at the other (Fig. 2d). 

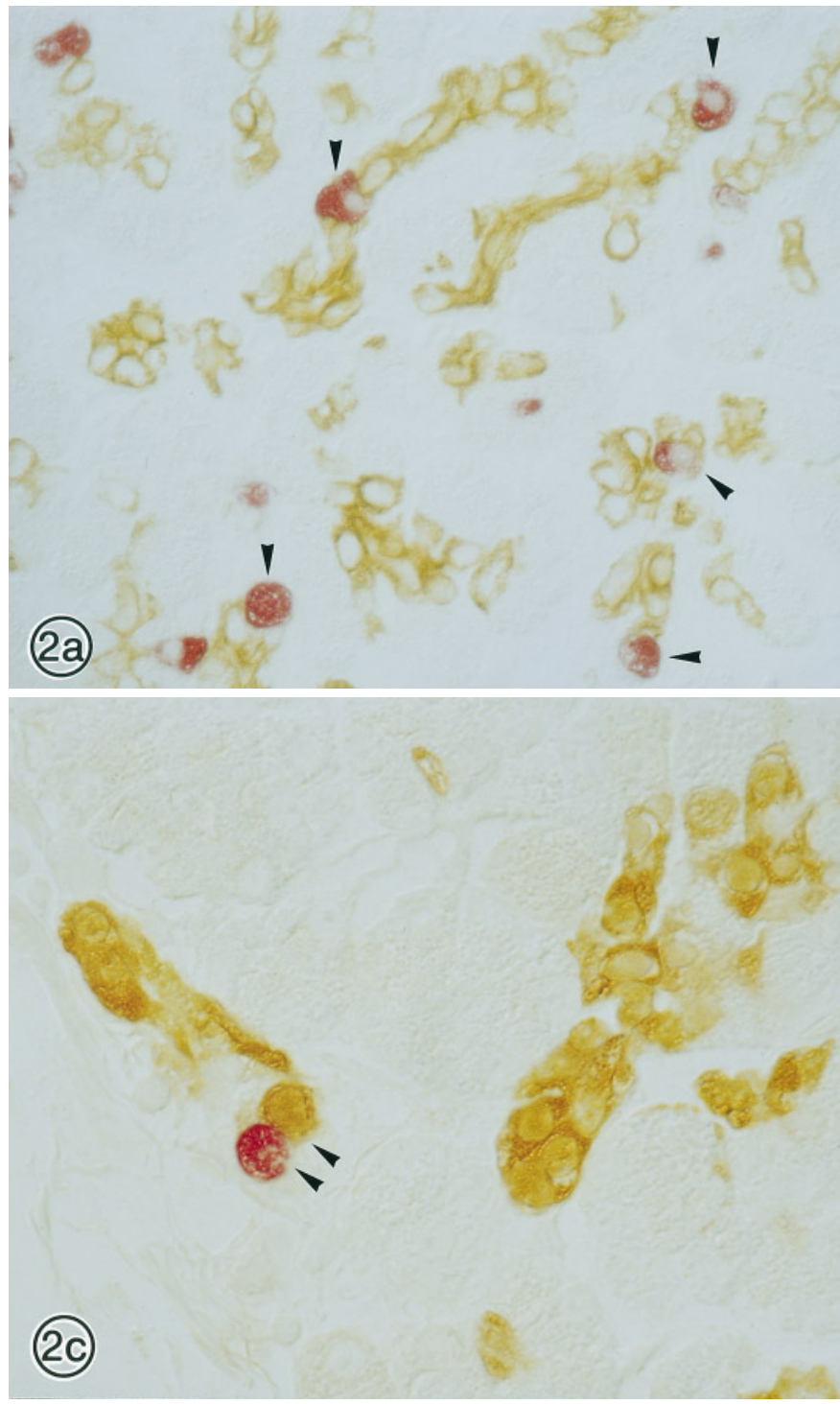

Fig. 2a-d. Double immunohistochemical localization of insulin (red colour) and cytokeratin-19 (brown colour) (a,b,d), or insulin (red colour) and carbonic anhydrase-II (brown colour) (c) showing the association between ductal structures and beta cells. Arrowheads point to single beta-cells associated with a ductule (a), a ductal cell/beta-cell doublet (c), and a cell co-expressing the ductal marker and insulin in a polar fashion (d). Magnification: $\times 400(\mathbf{a})$ and $\times 650(\mathbf{b}-\mathbf{d})$

Proliferative activity. To find out whether there may be a higher proliferative activity in single than in islet beta cells, we performed immunohistochemical localization of the proliferation-associated marker Ki67. We found no double immunoreactive endocrine cell for insulin and $\mathrm{Ki} 67$ or glucagon and Ki67. In the exocrine pancreas, only $0.10 \pm 0.04 \%$ (range: $0.01-0.31$ ) of the acinar cells and $0.05 \pm 0.01 \%$ (range: 0.02 0.09 ) of the cytokeratin19-immunoreactive cells were Ki67-immunoreactive.
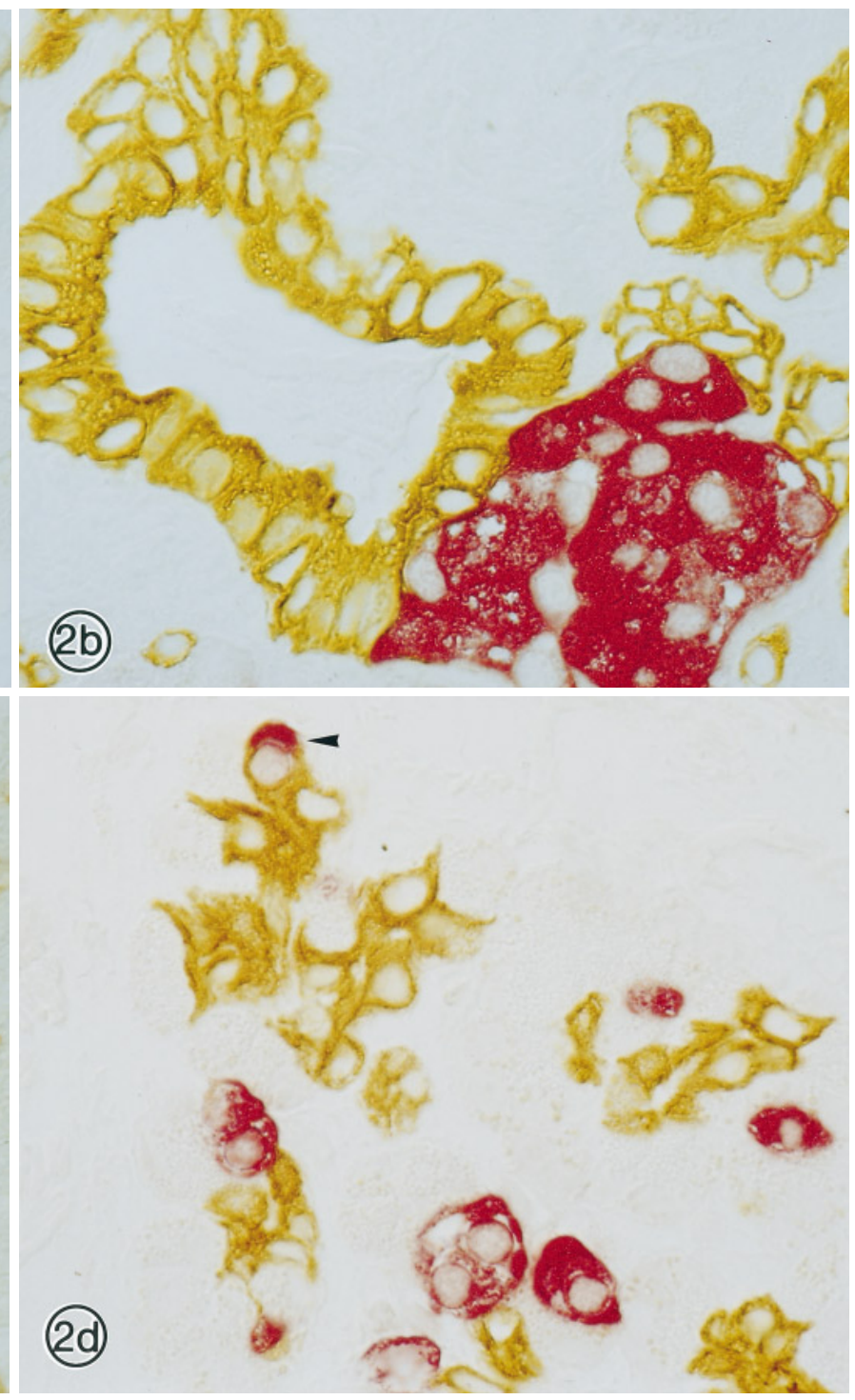

\section{Discussion}

The present microscopical analysis of human pancreas shows a relatively high number of beta cells located in small units outside the islets of Langerhans. In most quantitative studies, islets of Langerhans were identified as having a diameter of 50-60 $\mu \mathrm{m}$ and more [6-8]. They are further defined as vascularized micro-organs [7] with insulin-containing beta cells, somatostatin-containing delta cells, and either glucagon-containing alpha cells or pancreatic polypeptide-containing PP-cells. The present study reports that 15 percent of the beta cells in an adult human pancreas occur in units smaller than $20 \mu \mathrm{m}$ diameter without any association with glucagon-, somatostatin-, or PP-containing cells. These small insulin-immunoreactive units occurred at the same frequency in different anatomical regions of the gland. Such beta-cell units have also been noticed by Rahier et al. in 4 autopsy cases [9]. They are only rarely encountered in the adult rat pancreas where they represent less than $1 \%$ of all beta 
cells $[5,10]$. It is not clear whether these beta cells exhibit the same functional activities as those which are organized in islets. However, their occurrence as single cells and/or their different environmental conditions are expected to keep them in a different functional state [11], and their smaller size is compatible with an earlier stage in their life cycle. Single beta cells might represent an early stage of differentiation, which is thought to proceed during budding from their progenitors in the ductal epithelium [2, 12-14]. This could explain their high incidence in fetal and neonatal organs, and their re-appearance during regeneration [5, 10, 13-17]. Their topographic association with ductular cells, as reported here, therefore suggests beta-cell neogenesis occurs through a budding process. If so, the high percentage of "budding" beta cells would indicate the presence of numerous progenitor cells in the adult human pancreas.

In normal individuals, virtually none of these beta cells expressed the Ki67 marker, indicating their lack of proliferative activity. It is possible that beta-cell renewal depends on proliferation of insulin-non-immunoreactive progenitors in the duct and differentiation into insulin-immunoreactive cells during budding off from the duct. Insulin-immunoreactive cells that express the Ki67 marker were also absent during midand late gestation, where there is very active betacell neogenesis [3]. These observations are therefore compatible with the view that human beta cells under normal conditions are terminally differentiated and mitotically inactive. Our observations of duct cell/islet cell doublets and of cells co-expressing a ductal marker and insulin further indicate that duct cell differentiation to beta cells occurs in the human pancreas.

The availability of ductal cell markers also made it possible to determine the relative proportion of ductal cells in the exocrine lobules of the adult human pancreas. It was found that they represent nearly one third of the cells, markedly higher than previous morphological estimations of $2-11 \%$ [1]. This high frequency of ductal cells was similar in different anatomical regions of the gland. Without cell-specific markers, intercalated ductules, which have no clear lumen, may go unnoticed which would lead to an underestimation of the ductal cell number. Our observations confirm a previous electron microscopic study where a high frequency of ductular cells was noted in the human pancreas [18]. Now that human duct cells can be better identified, projects can be intensified to recognize the beta-cell progenitor cells which may represent a duct cell subpopulation with a potential for beta-cell neogenesis and regeneration. Also, more information must be collected on the population dynamics of human beta cells. Models that have been established for the growth potential of rat beta cells [19] may not be valid for the human pancreas where, as suggested by our findings, neogenesis from precursor cells may be rela- tively more important and replication of beta cells less so.

Acknowledgements. The authors are grateful for the technical efforts from Wen-Gao Lu, Jocelyn Deang, and Emmy De Blay. This work was supported by grants from the Fund for Scientific Research (FWO) (G.0041.96 and 3.0057.94), the Juvenile Diabetes Foundation International (DIRP 1995-2000), and the European Community (BMH4-CT 95-1561).

\section{References}

1. Githens S (1988) The pancreatic duct cell: proliferative capabilities, specific characteristics, metaplasia, isolation, and culture. J Pediatr Gastroenterol Nutr 7: 486-506

2. Slack JMW (1995) Developmental biology of the pancreas. Development 121: 1569-1580

3. Bouwens L, Lu WG, De Krijger R (1997) Proliferation and differentiation in the human fetal endocrine pancreas. Diabetologia 40: 398-404

4. Lu WG, Pipeleers DG, Klöppel G, Bouwens L (1996) Comparative immunocytochemical study of MHC class II expression in human donor pancreas and isolated islets. Virchows Arch 429: 205-211

5. Wang RN, Bouwens L, Klöppel G (1994) Beta-cell proliferation in normal and streptozotocin-treated newborn rats: site, dynamics and capacity. Diabetologia 37: 1088-1096

6. Hellman B (1959) The volumetric distribution of the pancreatic islet tissue in young and old rats. Acta Endocrinologica 31:91-106

7. Bonner-Weir S, Orci L (1982) New perspectives on the microvasculature of the islets of Langerhans in the rat. Diabetes 31: 883-889

8. Bonnevie-Nielsen V, Skovsgaard LT, Lernmark A (1983) Betacell function relative to islet volume and hormone content in the isolated perfused mouse pancreas. Endocrinology 112: 1049-1056

9. Rahier J, Goebbels RM, Henquin JC (1983) Cellular composition of the human diabetic pancreas. Diabetologia 24: 366-371

10. Wang RN, Klöppel G, Bouwens L (1995) Duct-to-islet cell differentiation and islet growth in the pancreas of ductligated adult rats. Diabetologia 38: 1405-1411

11. Pipeleers D (1987) The biosociology of pancreatic B-cells. Diabetologia 30: 277-291

12. Like A, Orci L (1972) Embryogenesis of the human pancreatic islets: A light and electron microscopic study. Diabetes 21[Suppl 2]:511-534

13. Cantenys D, Portha B, Dutrillaux MC, Hollande E, Roze C, Picon L (1981) Histogenesis of the endocrine pancreas in newborn rats after destruction by streptozotocin. Virchows Arch B (Cell Pathol) 35: 109-122

14. Dutrillaux MC, Portha B, Roze C, Hollande E (1982) Ultrastructural study of pancreatic $\beta$ cell regeneration in newborn rats after destruction by streptozotocin. Virchows Arch B (Cell Pathol) 39: 173-185

15. Bonner-Weir S, Baxter LA, Schuppin GT, Smith FE (1993)A second pathway for regeneration of adult exocrine and endocrine pancreas. A possible recapitulation of embryonic development. Diabetes 42: 1715-1720

16. Gu D, Sarvetnick N (1993) Epithelial cell proliferation and islet neogenesis in IFN-g transgenic mice. Development 118: 33-46

17. Rosenberg L, Vinik AI, Pittenger GL, Rafaeloff R, Duguid WP (1996) Islet-cell regeneration in the diabetic hamster pancreas with restoration of normoglycaemia can be induced by a local growth factor(s). Diabetologia 39: 256-262

18. Tasso F, Stemmelin N, Sarles H, Clop J (1973) Comparative morphometric study of the human pancreas in its normal state and in primary chronic calcifying pancreatitis. Biomedicine 18: 134-144

19. Finegood DT, Scaglia L, Bonner-Weir S (1995) Dynamics of $\beta$ cell mass in the growing rat pancreas. Estimation with a simple mathematical model. Diabetes 44: 249-256 